\title{
27. アジア太平洋地域における地球温暖化対策の 計画的推進方策に関する研究 \\ A STUDY ON PLANNING APPROACH TO THE REGIONAL COOPERATION FOR CLIMATE CHANGE IN ASIA AND THE PACIFIC
}

\author{
谷津龍太郎 ${ }^{*}$ - 山田和人** - 野池達也*** \\ Ryutaro Yatsu Kazuto Yamada Tatsuya Noike
}

\begin{abstract}
As a part of a study on desirable structure of environmental planning in Asia and the Pacific region, questionnaire survey and stocktaking survey were conducted in order to identify the needs of thematic plan for regional cooperation on climate change. A questionnaire consists of the questions on current situation, constraints and needs of policy and measures for climate change was sent to the national focal point of 23 countries in this region. In stocktaking survey, various documents and reports from bilateral as well as multilateral cooperation agencies were collected. As a result of the questionnaire survey, a half of the counties have prepared GHGs inventory, national plan for sustainable development and policy \& measures. Most countries are facing problems and constraints including lack of coordination mechanisms among government agencies, trained personal in public and private sector, cleaner technology and financial resources even multilateral as well as bilateral cooperation agencies have been stimulating technical and financial cooperation with counties in this region. In order to bridge the gap, following actions are identified as the needs of regional cooperation: creation of information network, capacity building, policy integration, activities in various regional forum, strengthening multilateral and bilateral cooperation, research and studies, awareness raising and role of mass media, and activities in private sector. Based on the analysis of the regional characteristics of GHGs emission structure, mitigation measures for land use change is identified as a area of study to be intensified.
\end{abstract}

KEYWORD; Climate Change, Regional Cooperation, Environmental Planning, Asia-Pacific Region

\section{1. はじめに}

地球温暖化対策は、国連気候変動枠組条約(UNFCCC)に基づき、国際的な連携の下で進められているが、 先進国と途上国との間には目標設定や対策実施の方法を巡り多くの課題が残されている。アジア太平洋地域 においては、1990 年代初頭から専門家レベルで地球温暖化対策に関する情報や経験の交流が行われるなど、 地域協力の経験が蓄積されてきている。アジア太平洋地域は、人口規模や経済的ポテンシャルから見て今後 の地球温暖化対策の鍵を握っている地域であり、国際機関や二国間援助機関も域内各国との協力を強化しつ つある。今後、リージョナルレベルの協力を具体化する中で、先進国と途上国との協調を図っていくことが 期待されている。

こうしたことを背景として、アジア太平洋地域の環境計画の体系化に関する研究の一環として、地球温暖 化対策に関する地域協力の計画課題を抽出するため、域内の 23 力国を対象にクエスチョネア・サーベイ (questionnaire survey)を行うとともに、域内各国と協力事業を実施している多国間、二国間の援助機関を対象 としてストックテーキング・サーベイ(stocktaking survey)を実施した。

\section{2. 研究の目的}

本研究の目的は、以下の 3 点である。

(1)アジア太平洋地域の開発途上国の地球温暖化対策への取組の現状と問題点の把握

(2)多国間・二国間援助機関の途上国に対する支援の状況の把握

(3)地球温暖化対策に関するリージョナルレベルの協力の計画課題の考察

3. 研究の方法

3-1 クエスチョネアー・サーベイ

*): 国際連合大学高等研究所 (United Nations University/Institute of Advanced Studies)

**):パシフィックコンサルタンツ（株） (Pacific Consultants Co., Ltd.)

***):東北大学工学部 (Tohoku University, Department of Engineering) 
(A)調査対象

表一 1 に示す 23 力国。

(B)調査項目

a. 各国の連絡担当者

b.温暖化対策のための組 織体制の整備状況

c. 温室効果ガス(GHG)排 出目録の整備状況

d.温暖化対策の政策手段

表-1 調查対象国

\begin{tabular}{|c|c|c|c|c|}
\hline 南西アジア & 東南アジア & 北東アジア & 旧ソ連 & 太平洋島しょ国 \\
\hline $\begin{array}{l}\text { バングラデシュ } \\
\text { インド } \\
\text { イラン } \\
\text { モルジブ } \\
\text { ネパール } \\
\text { パキスタン } \\
\text { スリランカ }\end{array}$ & $\begin{array}{l}\text { インドネシア } \\
\text { マレーシア } \\
\text { ミャンマー } \\
\text { フィリピン } \\
\text { シンガポール } \\
\text { タイ } \\
\text { ベトナム }\end{array}$ & $\begin{array}{l}\text { 中国 } \\
\text { 韓国 } \\
\text { モンゴル }\end{array}$ & $\begin{array}{l}\text { ロシア } \\
\text { ウズベキスタン }\end{array}$ & $\begin{array}{l}\text { フィジー } \\
\text { パプアニューギ } \\
\text { ニア } \\
\text { キリバツ } \\
\text { ツバル }\end{array}$ \\
\hline
\end{tabular}

を含む国家計画の整備状況(政策の枠組、影響緩和・経済セクター別対策、脆弱性評価・気候変動の影響 のモニタリングを含む調查研究、適応対策・対処能力向上・意識啓発）

e.UNFCCC に基づく国別通報の状況

f. 共同実施(AIJ)への取組状況

g.制度的枠組及び適正技術に関する情報へのアクセスを含む地域協力を促進する上での課題や対処方法 (C)調査実施時期

1997 年 7 月 10月

(D)調査方法

調査票を各国政府の温暖化対策フォーカルポイントに送付し、各国政府としての回答を得た。 3-2 ストックテーキング・サーベイ

1997 年 7 月に、環境庁の主催によって山梨県で開催された「第 7 回アジア太平洋地球温暖化セミナ一」に出 席した国際機関や二国間援助機関に対し、資料提供を要請するとともにインタビューを行った。また、出席 のなかった機関についても電子メール等を通じて同様の調査を行った。さらに、UNFCC に基づく先進各国 の国別通報報告書、各機関のウェブサイトに掲載されている資料や情報を入手した。

\section{4. 調査結果}

4-1 クエスチョネア・サーベイ

(A)概況

各国の取組状況は、表一 2 に示すとおりである。以下、その概要を述べる。

a.GHG 排出目録については、インドネシア、バングラデシュなど 10 力国で整備済。中国、タイ、マレー シアなど 9 カ国で整備中、イラン、パプアニューギニアなど 4 力国が整備に未着手。対象ガスについて は、二酸化炭素はすべての国が対象としており、メタンについてはシンガポール 1 力国、西酸化窒素に ついてはスリランカ、中国等 4 力国を除き対象としている。なお、排出量の計算手法については、気候 変動に関する政府間パネル(IPCC)の改正ガイドラインは大部分の国で入手はしているものの、これに基 づいて算定を行った国はモンゴル等 3 力国のみである。

b.国レベルの計画については、国別アジェンダ 21 など持続可能な開発を実現するための総合的な計画を 策定している国が、中国、マレーシア等 6 力国である。インドネシアやタイ等 8 力国では、こうした計 画を策定中。また、温暖化対策に焦点を当てた計画を策定している国は、インドネシアのみ。政策手段 については、排出削減を含む影響緩和策、脆弱性評価と適応策、調查研究とモニタリング、意識向上と 教育について調査を実施した。影響緩和策については、約半数の国で計画は策定されているが、具体的 な行動はとられていない。脆弱性評価については、過半の国で何らかの調査研究が行われている。対処 能力向上の必要性は同様に過半の国で認識されているが具体的行動に着手した国はない。意識啓発につ いては、約半数の国で計画が策定され、8 力国で学校教育やマスメディアを通じた取組が行われている。 c.AIJについては、中国、インドネシア、タイ等 7 力国で、AIJ への取組を進めるための国内の枠組が整備 されている。

(B)問題点、課題及びそれらへの対応方法

各国の政策担当者が指摘した問題点、課題、それらへの対応の方法は以下のとおりである。

a. GHG 排出目録の作成については、多くの国がデータの不足とトレーニングされた人材の不足をあげた。 
特に、中国等は、それぞれの国に特有な 排出原単位の必要性をあげた。インドは、 一層の調查研究と内部の能力向上をあげ、 ネパールは GHG 吸収源の評価が最も問 題があるとしている。また、フィジーは IPCC の方法論は島しょ国には詳細にわ たり過ぎる点を指摘した。以上の問題点 や課題への対応策としては、経験と情報 を交換するための地域的・国際的ワーク ショップやセミナーの開催、定期的な専 門家のトレーニング、国特有の排出原単 位算出に関する野外実験活動の促進、モ ニタリングシステムの改善、国際的専門 家による指導・助言があげられた。

b. 政策的対応については、エネルギー統計 など政策の企画立案の基礎的データの不 確実性、国際機関からの支援が不十分で あること、ローカルレベルでの人材や予 算の不足、国家開発計画における優先度 の低さ、関係省庁間の調整や関連政策分 野との調整メカニズムの欠如、対策実施 に必要な資金及び技術の制約、政府職員の地球温暖化とその影響に対する知識の不足、政策決定者の地 球温暖化対策に関する意識の低さ、環境法制度の未整備をあげている。これに対する対応方法としては、 政府部内の温暖化対策のための組織の整備、関係省庁の参画を得たハイレベルでの政策決定、経済セク タ一別計画の策定実施に対する資金的技 術的協力、国際協力の下でのローカルレ ベルの人材の育成、リージョナルレベル での国際協力や二国間協力による人材育 成、専門家の交流、ナショナルレベルで の地球温暖化対策委員会の設立、パーソ ナルコンピュータを用いた情報ネットワ 一クの整備があげられた。

c. AIJについては、民間も含めた各主体の意 識の低さ、環境担当省庁の訓練された職 員の不足、GHG 排出抑制対策の知見の不 足、GHG ベースラインデータの久如、ロ 一カルレベルの管理能力の欠如、民間セ クターへの情報提供の不足、AIJ の機会と 利点への情報と理解の不足、政治的リ一 ダーや官民の AIJ 自体に関する情報の不 足、AIJ のパートナーの特定の困難さ、を 問題点、課題としている。これらに対応 するための方法としては、エネルギー・ 再生可能エネルギー・森林に関する実行 可能なプロポーザルの作成、AIJ 実施のた めの制度の整備、職員の訓練、ナショナ ル・ローカルレベルでの対処能力向上のためのプロジェクトプロポーザルの作成、ワークショップやセ ミナーの開催、リージョナルレベルの協力の促進、情報ネットワークを通じたパートナーの特定があげ
1. GHG 排出目録

表ー3 各国が指摘した問題点・課題

・国固有の排出原単位の必要性(中国、ベトナム)

・活動量に関するデータの久如・精度の低さ(中国、フィリピン、ベトナム、 モンゴル、キリバツ、バングラデシュ)

・人材・政府内部の能力の不足(インド、モルジブ、スリランカ、マレーシア、 タイ、ツバル)

・吸収源の評価(ネパール)

・简易な算定手法の必要性(フィジー)

・国际的な情報交換の機会の欠如(ウズベキスタン)

・IPCC のフォーマットに対応するデータの欠如(インドネシア)

2. 政策的対応

・政策企画立案の基礎的データの不足(バングラデシュ)

・政府部内での調整メカニズムの欠如(フィリピン、韓国、モンゴル、フィジー)

・対策実施のための人材・資金・技術の不足(ネパール、マレーシア、ミャン

マー、フィリピン、シンガポール、ベトナム、ウズベキスタン)

・技術開発・普及のためのインフラの未整備(ベトナム)

・法制度の未整備ツバル)

・ローカルレベルでの経験と資金の不足(インドネシア)

・政策決定者の意識の低さ(ネパール、ベトナム)

・計画策定一の国際的支援の不足(スリランカ)

・国家開発計画における優先度の低さ(韓国)

3. AIJ

・民間を含めた各主体の理解の不足(スリランカ、インドネシア、タイ、ベト ナム、フィジー)

• GHG ベースラインデータの久如(インドネシア)

・ローカルレベルの管理能力の低さ(インドネシア)
・AUJのパートナーの特定・の困難さ(ウズベキスタン)
表一 4 各国が指摘した問題・課題への対応策

1. GHG 排出目録

・メタン排出量等不足している知見の充実(バングラデシュ) パキスタン、インドネシア)

・リージョナルレベルの研修・ワークショップの開催(スリランカ、マレ ーシア、フィリピン、タイ、ウズベキスタン、ツバル)

・国内主要地域での調查の実施(ベトナム)

・関倸経済セクターの活動量のモニタリング(ベトナム)

・フィールド実験による特定の排出係数の算出(ベトナム、中国、モンゴ ル)

・既存データの精度向上(中国)

・リージョナルレベルの情報ネットワークの整備(ウズベキスタン)

・継続的な情報収集システムの整備(キリバツ)

2. 政策的対応

・関係省庁での温暖化担当組織の設置(バングラデシュ)

・政府のハイレベルでの意思決定・意識啓発(ネパール、フィジ)

・政府部内の横断的調整期間の設置(モンゴル)

・計画策定・実施一の資金・技術協力(スリランカ、フィリピン)

・特にローカルレベルの担当者の研修(インドネシア)

・リージョナルレベルでの研修・尃門家交流(マレーシア、フィリピン、 ベトナム)

・リージョナルレベルの情報ネットワークの整備(ウズベキスタン)

・法制度の整備(ツバル)

3. AIJ

・対処能力向上のためのプロジェクトプロポーザル作成(インドネシア)

・情報普及と可能性検討のためのセミナーの開催(インドネシア、タイ)

・リージョナルレベルの情報ネットワークを通じたパートナーの特定 (ウズベキスタン、ベトナム)
・対処能力向上のための資金・技術協力(インド、モルジブ、ネパール、 
られた。

(C)リージョナルレベルの協力の提案

今後のリージョナルレベルの国際協力の課

題としては、以下の事項があげられた。

a. 研究成果等の科学的知見の普及、気候変 動のモニタリング、適応対策・排出抑制 対策に関する協力

b.資金協力の強化、クリーナーテクノロジ 一の普及、一方向の援助でなく双方向の グローバルパートナーシップの確立

c.リージョナルレベルの情報ネットワーク、 情報センターの整備

d.域内各国間の排出原単位、影響評価及び

表－5＼cjkstart各国が指摘したリージョナルレベルの協力 の提案

・データの収集・国家対応戦略策定に関する協力(PNG)

・国家行動計画に関するワークショップの開催(キリバツ)

・情報交換・技術移転のためのリージョナルネットワークの整備(ミャンマー、 タイ、ベトナム、モンゴル、ウズベキスタン、フィジー)

・既存の情報の所在・内容の特定(フィリピン)

・セミナー、ニュースレター、インターネット等を通じた情報交换(中国)

・専門家の交流(排出係数、影響評価、気候シナリオ)(マレーシア)

・UNFCC への対応に関するリージョナルセミナーの開催(マレーシア)

・調查研究への資金・技術協力(中国)

・技術移転に関するリージョナルセンターの設立(マレーシア)

・科学技術・経済社会面に関する研究者のネットワーク化(マレーシア)

気候変動シナリオの専門家の交流、気候変動枠組条約への対応に関するセミナーの開催、技術移転に関 するセンターの整備、気候変動の科学技術・経済社会面の連携のとれた協力の促進

e.リージョナル、サブリージョナルレベルでの情報交換、技術協力

f. 気候変動に関する既存の情報の所在、内容等特定

g.セミナー、ニュースレター、インターネット、ワークショップを通じた情報交換、先進国・途上国の共 同研究への資金・技術協力

4-2 ストックテーキング・サーベイ

多国間、二国間協力を通じた途上国の取組の支援状況は、以下のとおりである。

(A)多国間協力の状況

a. 国連開発計画(UNDP) と地球環境ファシリティ(GEF)は、UNFCC に基づく各国の通報の準備を支援する イネイブリング・アクティビティ(Enabling Activities)と称する支援事業を実施。本地域では、スリランカ、 マレーシア等 6 力国が参加。

b.UNDP、GEF、UNFCC 及び国連研修研究機関(UNITAR)は、途上国の開発政策の目標の中に温暖化対策 を統合し UNFCC の実施能力を向上させるための研修プログラムとして、CC:TRAIN を実施。ベトナム、 南太平洋島しょ国等が参加。

c.アジア開発銀行(ADB)は、1993 年からアジア最低コスト GHG 削减戦略(ALGAS) プロジェクトを中国、 インド、インドネシア、ベトナム、北朝鮮等 12 カ国を対象に実施。このプロジェクトでは、GHG の算 定、対策技術の検討、削減戦略の策定等を支援。

d.アジア太平洋経済社会委員会(ESCAP)は、1993 年以降、対処能力向上のためのアジア太平洋地域ネット ワークの整備に向けた取組を行っており、専門家会合を開催してその具体的内容を検討。

(B)二国間協力の状況

a. 日本は、1991 年以降インドネシア、西サモア、フィジ一等を対象として、国家対応戦略の研究や脆弱性 評価に関する協力を実施。また、グリーンイニシャティブを通じて途上国協力を強化する方針。

b.米国は、1993 年以降米国国別研究プログラム(USCSP)を通じて、アジア太平洋地域のバングラデシュ、 インドネシア、中国等 15 力国を含め全世界で 50 力国以上を対象に、GHG 排出量目録、脆弱性評価等 に協力。1995 年に新たに国家行動計画支援(SNAP)を開始し、国別の研究成果を行動計画に結び付ける ことを目的に、域内ではインドネシア、中国、フィリピン等 8 力国への協力を実施。

c. ドイツは、パキスタン、インドネシア、中国等域内の 5 力国を対象として、排出シナリオの構築、GHG 排出抑制のための技術的政治的オプションの分析等への協力を実施。

d.オランダは、バングラデシュとベトナムの沿岸域を対象とした脆弱性評価、モンゴル、カザフスタン、 ブータンを対象とした温暖化対策政策策定支援を実施。

(C)多国間、二国間協力の概況

域内途上国の支援プロジェクトとしては、多国間はADB による ALGAS、二国間では米国の USCSP が代 表的なものである。いずれも GHG 排出目録の作成、脆弱性評価、低コス卜対策の確立、国家戦略の策定な ど調査研究が中心である。また、影響緩和策に関する二国間、多国間プロジェクトの概要を表一6に示す。 
影響緩和策としては、太陽光、水力、バイオマスなど代替エネルギーの供給サイドの対策が主となっている。

\section{5. 開発途上国の GHG 排出構造}

図一 1 に、域内途上国の GHG の排出構造を示す。ここから途上国においては、エネルギーや工業プロセ スに起因する GHG は 50\%以下で あり、反面、土地利用の変更や農 林業にに伴う GHG の排出量はい ずれの国においても50\%を超えて いる。

\section{6. 考察}

リージョナルレベルの国際協力 の課題を考察する。まず、各国が 指摘した問題点・課題とそれへの 対応方策を整理すると表一 7 のと おりである。

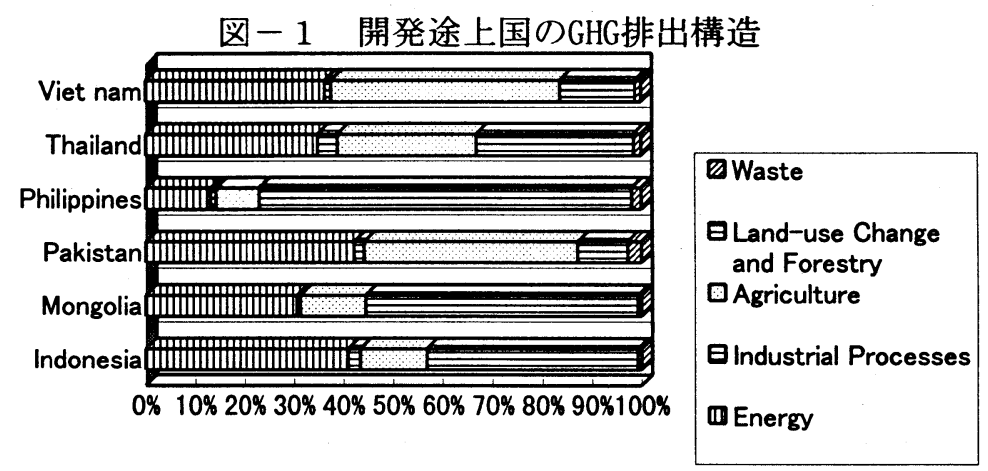

(出典)ALGAS Interim Results(ADB, 1997)のデータを基に作図

これに対し、従来から実施されてきた国際機関や先進国から途上国への国際的支援を整理すると、(1) GHG 排出量目録の作成、

(2)脆弱生評価、(3) 国家戦略の策定、 (4)低コスト対策の 検討、(5)研修の実 施と整理、となる。 表一2をみると、 国際的な支援の下 表 -7 各国が指摘した問題点・課題と対応方策

\begin{tabular}{|c|c|}
\hline 問題点・課題 & 対応方策 \\
\hline (1)政策立案の基磷的データの欠如、 & (1)調査研究への資金・技術協力 \\
\hline (2)専門的知見を有する人材の不足等の対応能力の不足 & (2)対処能力向上のためのワークショップ等の開催 \\
\hline （3政府・経済セクターを通じた認識の低さ & (3)政府のハイレベルでの意思決定 \\
\hline (4)国内の調整メカニズムの不備 & (4)政府部内の調整機関の設置 \\
\hline (5)対策に必要な資金・技術の不足 & (5)計画策定・実施への資金・技術協力 \\
\hline （6法制度の未整備 & (6)法制度の整備 \\
\hline (7)国際協力のパートナーの特定の困難さ & (7)リージョナルレベルの情報ネットワークの整備 \\
\hline
\end{tabular}
で、多くの国が GHG 排出目録の作成を終えるか、作業中である。また、政策についは計画は過半の国で策定されているもの の、意識啓発以外は実施に移されていない。今後、残された課題に対する国際的支援の拡充が必要である。 図一 1をみると、土地利用変化や農業に起因する GHG の排出が $50 \%$ 以上を占めている。今後、この分野の 調査研究を進め効果的な対策を確立する必要がある。さらに、途上国からのリージョナルレベルでの協力の 提案を踏まえ、以下の分野に関する協力を推進する必要がある。(1)リージョナルレベルの情報ネットワーク の整備(対策技術の普及、経験や情報の交流、意識啓発、協力のパートナーの特定等)、(2)リージョナルレベ ルの各種フォーラムにおける温暖化問題への対応(政府、民間、学会等アジア太平洋地域の各種フォーラムに おける温暖化問題への取組強化)、(3)対処能力の向上(政府、民間を通じた人材育成、制度の整備)、(4)調查研 究(脆弱性評価、各国特有の排出原単位の整備)

謝辞 : 鈴木克徳前環境庁地球環境部温暖化国際対策推進室長には、本調査の共同実施者としてさまざまな協 力をいただいた。ここに記して謝意を表します。

(参考文献)

1. Report of the Expert Group Meeting of Regional Cooperation on Climate Change, Economic and Social Commission for Asia and the Pacific(ESCAP), 1996

2. A Study of Least-Cost Greenhouse Gas Abatement Strategy(ALGAS) Interim Results, Asian Development Bank(ADB), 1997

3. Implementation Status of the UN Framework Convention on Climate Change in Selected Countries of Asia and the Pacific, Environment Agency of Japan(EAJ), United Nations University/Institute of Advanced Studies(UNU/IAS), 1997

4. Quarterly Operational Report, Global Environmental Facility(GEF), 1997

5. National Communications: Australia, USA, Canada, Netherlands, Norway, Finland, UK, Switzerland, Sweden 


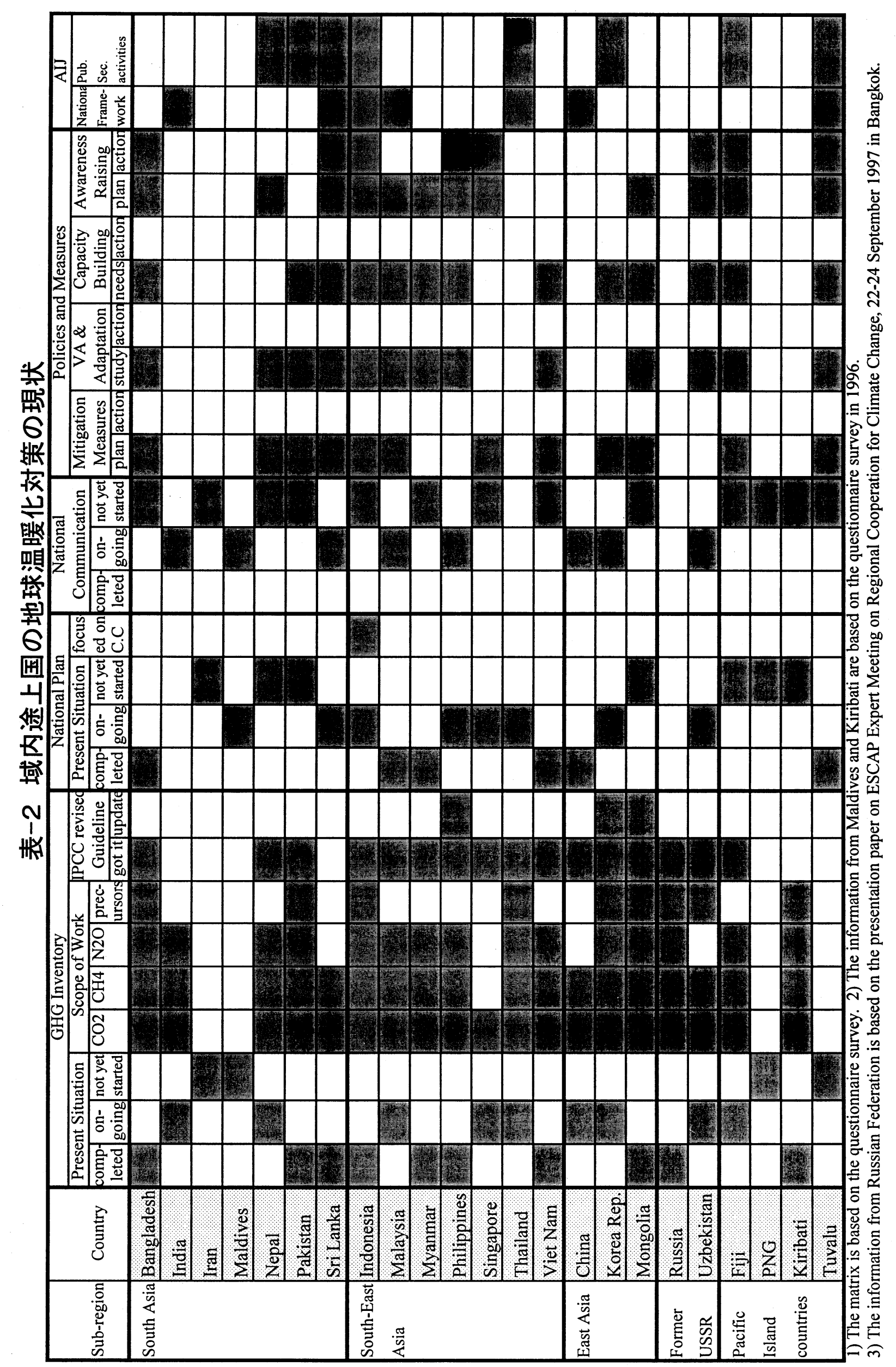




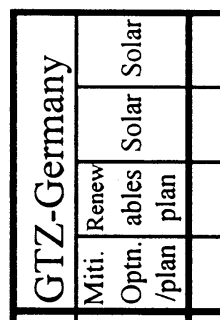

埖

冡

6

군

少安这

只

嵪 嵓

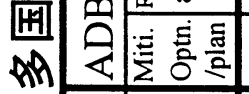

"रु

सर्ष

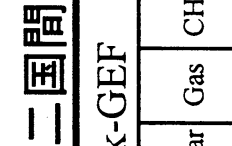

No 光

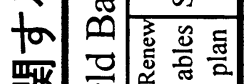

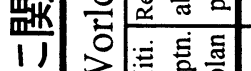

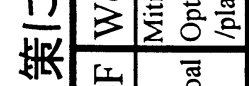

足 臭

㟵 光 志

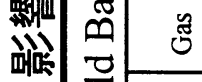

०

1 2

斐

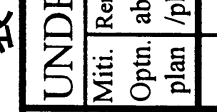

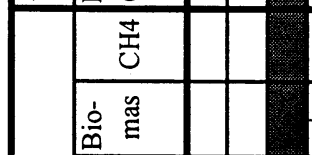

至 旁

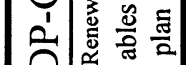

司焉

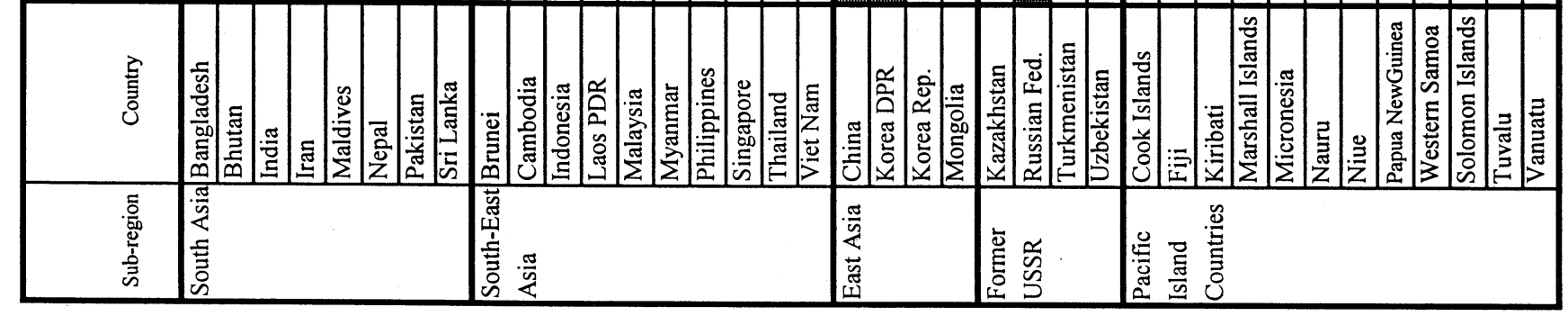

